\section{Rusbehandling på øverste hylle}

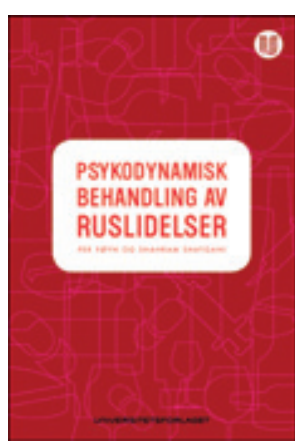

Per Arne Føyn, Shahram Shaygani Psykodynamisk behandling av ruslidelser 244 s, ill. Oslo: Universitetsforlaget, 2010. Pris NOK 319 ISBN 978-82-15-01526-2

For noen år siden skrev én av denne bokens forfattere et avisinnlegg der han mente at en rekke avvik som Helsetilsynet hadde påvist ved rusomsorgen i Oslo, måtte møtes med mange nye leger og psykologer. Siden jeg er en av dem som mener at rusvernet allerede er overmedikalisert, sendte jeg straks inn et motinnlegg der mitt sluttpoeng var: «Heller mange flere profesjonelle omsorgsarbeidere enn noen få kostbare leger og psykologer med dårlig tid.» Min skepsis var derfor ekstra stor da jeg åpnet denne boken, for jeg regnet med at den var et lynkurs i psykodynamisk behandling som hvem som helst kunne ha nytte av.

Men jeg ble positivt overrasket. Boken viste seg å være en grundig og kunnskapstung innføring i psykodynamisk psykoterapi generelt og i hvilken grad og på hvilken måte slik behandling kan benyttes ved rusproblemer. Ikke noe lynkurs, men en balansert gjennomgang av hva som kreves av både pasient og terapeut. Et gjennomgående tema er hvordan overføring og motoverføring er sentrale elementer i behandlingen, og hvor viktig det er å ha en høy bevissthet omkring disse fenomenene.

Forfatternes posisjon kan illustreres med følgende sitat (s. 141): «Psykoterapi er et nyttig supplement for rusbehandlingen, men neppe nok som eneste behandlingsmetode, særlig hvis pasienten har en langtkommen ruslidelse med sosiale komplikasjoner som følge.» De viser også tydelig hvordan den største trusselen mot effektiv psykoterapi er nettopp rusen - det er ikke mulig å drive effektiv psykodynamisk behandling med en person som ruser seg. En diskusjon som de dessverre ikke tar i den sammenhengen, er om det er realistisk å tilby slik behandling til pasienter som får substitusjonsbehandling med metadon eller buprenorfen, som etter hvert er blitt det vanligste behandlingstilbudet for narkomane her til lands. De berører temaet så vidt på side 153: «Kvotemedisiner er kanskje i noen tilfeller en forståelig nødløsning [...] Det handler om at en behandler forsøker å redusere de negative konsekvensene av rusavhengighet ved å gjøre pasienten avhengig av noe annet, og i det reduseres pasientens motivasjon for endring.» Dermed blir psykodynamisk behandling et alternativ, og ikke et supplement, til legemiddelassistert rehabilitering (LAR).

Psykodynamisk behandling av ruslidelser er behandling på øverste hylle, forbeholdt de pasientene som kan holde seg rusfrie over lang tid og samtidig følge et krevende terapeutisk opplegg, individuelt, i gruppe eller i et psykodynamisk behandlingsmiljø. Det er den behandlingen jeg ville valgt dersom jeg hadde et slikt behov. Og ved å lese denne boken forstår jeg lettere hvorfor medforfatter Per Føyn etterlyste flere leger og psykologer i sitt innlegg i Dagsavisen i august 2006. For selv om det på omslaget står at boken vil være av interesse for alle som berøres av ruslidelser, så er denne behandlingsformen ikke for noviser, her kreves både erfaring og innsikt. Vi får håpe at den nye spesialiteten rusmedisin vil inkludere denne kompetansen, selv om den utgjør et av psykiatriens kjerneområder.

\section{Olaf Gjerløw Aasland}

Legeforeningens forskningsinstitutt

\section{Gjøkungen i Stockholm}

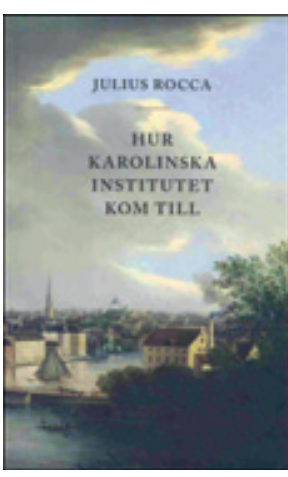

Julius Rocca

Hur Karolinska Institutet kom till

107 s, ill. Stockholm: Karolinska Institutet University Press, 2010. Pris SEK 135 ISBN 978-91-85565-41-2

Storebror blant skandinaviske medisinske fakulteter feiret 200 år i 2010, og det ble markert på mange måter. Foreliggende bok er en detaljert beskrivelse av en meget trang fødsel. For 200 år siden var Sverige «ett fattig och glesbefolkad rike i Europas norra utkant». I 1809 forsøkte kong Gustav 4. Adolf(1778-1837) å flykte midt på natten med statskassen, noe som ble forhindret av bankfullmektigen Fabian Reinhold von Fersen (1762-1818) under henvisning til at han manglet de rette blankettene. Etter militærkupp, folkeopprør og andre uroligheter valgte man å anmode Napoleon om hjelp: Familien Bernadotte ble etablert.

Midt i denne meget turbulente tiden ble grunnsteinen til Kungliga Karolinska Mediko-Kirurgiska Institutet lagt. Det tilsynelatende utgangspunktet var at man trengte feltskjærere, dvs. noen som kunne amputere, men enkelte hadde større tanker: Man ville etablere en moderne utdanning i medisin. Boken, som er meget detaljrik, tar opp en rekke tråder, og det er ikke alltid at man øyner begynnelse og slutt på tråden. Den kan leses ut fra flere synsvinkler:

1. En detaljrik skildring av helsetilstanden og legemangelen i Sverige for 200 år siden. Dette vil kunne glede historisk interesserte leger.

2. En gjengivelse av profesjonskampen mellom medisin og kirurgi. Dette vil nok ha interesse for en større leserkrets, men heldigvis, også dette er historie.

3. En beskrivelse av en langvarig kamp mellom etablerte miljøer, dvs. de medisinske fakultetene i Lund og Uppsala, og gjøkungen i Stockholm. Våpnene var mange og ikke alltid like blanke. Slike kamper pågår fremdeles, også i Norge, så her er det nok atskillig flere av Tidsskriftets lesere som vil nikke gjenkjennende.

Hvordan kunne gjøkungen i Stockholm overleve i kampen mot «The Establishment»? Forfatteren gir ikke noe klart svar på dette, 